\title{
Paideusis
}

\section{The Strange Phenomenon of the Private Music Lesson}

\section{Joan Munro}

Volume 6, Number 2, 1993

URI: https://id.erudit.org/iderudit/1073306ar

DOI: https://doi.org/10.7202/1073306ar

See table of contents

Publisher(s)

Canadian Philosophy of Education Society

ISSN

0838-4517 (print)

1916-0348 (digital)

Explore this journal

Cite this article

Munro, J. (1993). The Strange Phenomenon of the Private Music Lesson.

Paideusis, 6(2), 23-31. https://doi.org/10.7202/1073306ar

This document is protected by copyright law. Use of the services of Erudit (including reproduction) is subject to its terms and conditions, which can be viewed online.

https://apropos.erudit.org/en/users/policy-on-use/
This article is disseminated and preserved by Érudit.

Érudit is a non-profit inter-university consortium of the Université de Montréal, Université Laval, and the Université du Québec à Montréal. Its mission is to promote and disseminate research.

https://www.erudit.org/en/ 


\section{The Strange Phenomenon of the Private Music Lesson}

\section{Joan Munro, University of Alberta}

Music lessons have a different function from other extracurricular activities for which parents "sign up" their children. Unlike Brownies or T-Ball, music lessons seem to have some connection with a liberal education (music after all belongs to one of Hirst's "forms of knowledge") and also may be as necessary as any school subject when the child eventually makes a career choice. When a student enters university and wishes to take a music course, almost certainly that student must have had a prior "background" in music, and clearly anyone hoping to be a professional musician requires such a background. Yet a good music background is not acquired from courses taken in the student's elementary and secondary schooling. Some students gain a minimal music background in school, but never enough to handle post-secondary music education. Musical knowledge comes from private instruction, usually starting at a very young age.

The private music lesson is a strange beast in many ways. There is the elitism perpetrated by keeping serious music study out of the public school system; the central place given competition in music study; and the largely traditional way of studying music as compared with the more progressive approach taken in school education. Instead of addressing all these issues, I have chosen to accept the traditional approach of private music lessons as a given. Here $I$ intend to show how this approach can and does lead to some of the ends sought by modern education, namely autonomy, creativity, and self-realization.

I should first like to put to rest a common misconception: the notion that a child's musical education is merely a matter of training in a skill, the skill of music performance. Although the idea that students could or should be moulded like clay ended with the nineteenth century, it is sometimes hinted, even by those in the music business, that what is wanted in a musician is merely a person with the expertise to follow orders. For example, a recent article in the International Musician, the newspaper of the American Federation of Musicians, notes, "'[Some] music directors. . have stated openly that they prefer young, mouldable musicians' in their orchestras. This is totally contrary to the spirit of the Audition Code of Ethics and is a chargeable violation of Federal Equal Opportunity Laws." The violation, you will notice, is in the prejudice toward youth over age and the implicit judgement that older musicians are not mouldable, rather than in the "mouldability" criterion itself.

But it is not mouldability or even technical superiority that we admire in the very best musicians-the YoYo Mas, James Galways, Sills, and others whose names are not household words. We distinguish these musicians from the mechanical, uninteresting, or merely competent. We claim that the best musicians have something to say, are inspiring, bring new life to old works. Insofar as such qualities are learned and not innate, they are learned from teachers, just as technique and repertoire are. Indeed, fine musicians who have written autobiographies or books about performance are quick to cite their teachers as being responsible for their status in the music world. (See Galway and others cited in the references.) 
Let me describe the typical music lesson. It differs radically from the normal classroom lesson. The style is low on explanation and high on demonstration. Such verbalization as does occur is usually in the form of one-syllable commands ("Use the third finger here." "Play all this as one phrase."); criticisms ("No, no not like that."); praise ("Good, good, that's it."); metaphors ("Make it dance." "Push it forward." "Pick it up." "Sit back on the beat."); and shouts of encouragement ("More, more, that's it! Now you've got it!). Only occasionally will the teacher ask the student a question.

The plan of the lesson with a given teacher scarcely varies from one lesson to another. Certain material is assigned to be worked on in specified ways. The teacher checks the student's progress and moves on to new material and new ways of improving the previously assigned material. The lesson's content is technique and repertoire with some time reserved for sight reading and ear training. Unlike school subjects, there is little difference in lesson plan, content, or style from beginner to advanced levels, except that students in the latter category will likely devote more attention to interpretation and to exercises overtly aimed at specific technical skills .

All this is learning in the most basic sense of the word. Even interpretation consists almost entirely of teacher demonstration and student emulation. There seems no room for independent thinking or creativity. The form of the lesson, its content, and especially the style of teaching all differ from that used in regular classrooms.

The overall structure of an education in music performance is also of interest. Like more traditionally taught school subjects such as mathematics, learning is built from a base, block-by-block or step-by-step. Reading musical symbols is learned from the simplest to the most complex; listening skills are developed gradually; interpretive and physical abilities are cultivated over several years. But unlike even the most traditional school subjects, there is a high emphasis on competition. The musical festival is the most visible, but the examination system (in Canada through the Royal Conservatory or a regional system) with its syllabus of prescribed content and standards is also by nature competitive, albeit competitive against a standard. Long before students write departmental exams in school, those who study music seriously will have taken several music exams. And even where music exams are not the norm, periodic recitals are. The concept of being "the best" or "better than" is learned very early. By the age of thirteen or so, students are vying through auditions for places in bands, orchestras, summer camps, and master classes. Here, ranking is clear cut as well. There is one principal flute, one assistant principal, and the hierarchy continues downward.

One cannot but conclude that the ambience of a music education is, in a word, old-fashioned, like the school routine that the not-so-fictional Anne of Green Gables followed in Prince Edward Island in the early twentieth century: competition for marks, public demonstration of ability, a fairly strictly prescribed curriculum. It is a far cry from the typical lessons in standard school subjects, which (ideally) foster independent thought through discussion, reward originality and creative problem-solving, and de-emphasize competition, except perhaps for scholarships and university entrance. It is perhaps strange, then, that this seemingly authoritarian style of teaching music performance could lead to reflective, innovative musicians. 


\section{Autonomy}

To illustrate how studying music performance can result in a considerable degree of autonomy, I have chosen three examples from Donald A. Schon's Educating the Reflective Practitioner.

1. Bemard Greenhouse of the Beaux Arts Trio describes his lessons with Casals: "He would play a phrase and then have me repeat it. [He] demanded that I become an absolute copy. [After] several weeks. . I really had become a copy. . .and at that point. . he played through the piece and changed every bowing and every fingering. I sat there. . listening to a [totally different] performance which was heavenly."1 Schon comments, "[The] lesson is not that there are two right ways to perform the piece but that there are as many as the performer can invent and produce-each to be realized, phrase by phrase, through a precise co-ordination of technical means and musical effects, each to be achieved through painstaking experimentation."2 But Greenhouse learned more than this; he learned bow to build an interpretation.

2. An anonymous famous violin teacher questions a student about the character she feels each section of the piece has. On hearing that a particular section is reflective, the teacher says, "How would you make it really reflective?" She agrees with the student's suggestion and adds another of her own. She asks the student which she will use and accepts her comment, "I'll have to think about it." In such an instance, the teacher is helping the student to clarify her thinking and directing the student toward an acceptable solution to a problem. In true Socratic style, this teacher may simply be testing the student to see whether she is thinking of a suitable character for the piece (or whether she is thinking about it at all), but may also be working out a solution along with the student. Through this mutual problem-solving, the student again learns how to meticulously build an interpretation, but this time what is learned is the prerequisite mental activity of determining exactly what character she wants the piece to have, and how to set about finding ways to achieve the effect.

In both examples, to quote Schon again, "[The] student is invited, sooner or later, to attend to his own preferences and to take these, rather than external authority, as criteria to regulate his actions.",3

3. Schon introduces us to a situation in a master class where the teacher could be said to be attempting to change the student's interpretation. The teacher seems to want the student to conform, although the student does have an interpretation-a different one from the teacher's. ${ }^{4}$ Some of those listening to the lesson think the teacher is destroying the student's initiative; an already excellent interpretation is being ignored in favour of a different one. On the other hand, Schon and others present understand this lesson to be yet another demonstration of a way of designing a performance. ${ }^{5}$ The student and the class learn an alternative interpretation, which they can use or discard later, and they also learn the teacher's rationale for his interpretation, one that makes the music more meaningful than the student's good, but less thoughtful, approach.

In all these cases, students have learned to discriminate among a number of choices and to be painstaking and thoughtful in selecting one interpretation over another. This behaviour goes far beyond the practice of a skill, for both autonomous thinking and creativity are demanded. Further, no two performers will have exactly the same performance. (I will say more about this later.) 
The success of realizing the intended interpretation does, however, depend on the performer's skill. Schon's examples are all taken from advanced students who already have at their disposal superior technical skills. What could a piano teacher with a young student learning how to read the first few notes on the staff, or a flute teacher helping a thirteen-year-old make the first few sounds, do about independent thinking? Must students be told exactly what to do until a given level is achieved, at which time they are suddenly expected to make their own decisions? If there is anything that is patently obvious, it is that autonomy is not taught by authoritarian means. On the other hand, allowing children to play music in any way they choose can only limit their options later. Music teachers at an upper level despair over students with bad technical habits, who cannot make the kinds of sounds they would like. No responsible teacher allows this to happen. But how can a teacher help beginning students to think for themselves and not sacrifice their acquisition of essential knowledge, the knowledge they must have in order to make music that can be enjoyed by themselves and others? Even at the earliest levels, students can make simple choices without being "wrong." As Schon's examples show, there are many "right" ways to play a given musical passage. Even when the student is first becoming acquainted with the passage in question, even when she is as yet technically unable to put fingers or lips in the right place, her teacher may ask, "Which way do you like it?" and demonstrate alternatives. Sometimes, one way obviously sounds better. At other times, several ways might be equally good, and the student can choose one and work on the technique required to play the passage that way.

Very early, then, students begin to make choices. But there is no such thing as prolonged discussion over the best choice, as there might be in a social studies or English literature class. The proof is in the sound, not in the convincing argument. In music, there is much that cannot be said, need not be said, and, in fact, is better unsaid. On the wall of our local musicians' union office is a newspaper interview with "Big" Miller, a well-known blues musician. The headline reads, "I can't explain, but I can play you how it feels." When Casals tells his student, "Do it this way,"6 and demonstrates, he is saying the same thing. When the teacher of the master class tells the student to play the first subject as "wa pa pim" and the second, "na na na,"7 he too is describing (musically) how it feels. Before a student has mastered either the mental understanding or physical skills of playing "how it feels," the teacher can demonstrate musical possibilities and show the student how to achieve the desired results. In this way, a student can learn to respect another different way of playing, adopting, modifying, or eventually rejecting it altogether. At the same time, the student realizes that through trying out ideas, she comes to discriminate between them, and is free to choose what seems most congenial to her own individuality.

It should be clear by now that, ideally, music teaching can produce students who are autonomous in their thinking about musical problems. With good coaching, they can learn to interpret independently; to apply previously learned skills and theories to new situations; to relate the use of one idea in one passage to its effects on other facets of the music; and to do all this carefully, with attention, not just to detail, but to the overall effect. Schon calls the person who thinks in this way a "reflective practitioner," one who constructs or "frames" 
reality. A reflective practitioner of music sees the piece of music, its relation to other music and to other aspects of life, in a certain way, in a certain light. She is aware of her way of framing reality, but also aware of different frames. She builds a repertoire of exemplar situations that she can relate and apply to new situations. ${ }^{8}$ A musician is unlikely to have a conscious awareness of this procedure. What she does know is that she. understands the music in a certain way and tries to play it that way ("how it feels"). If it does not work or feel right, she tries something else. When she encounters problems, she draws on her repertoire of solutions learned through experience. ${ }^{9}$

In The Teacher, Allen Pearson has argued that a classroom teacher benefits by having the attributes of a reflective practitioner. Such teachers must be prepared for unforeseen scenarios by turning to their experiential knowledge, including exemplar situations, to make on-the-spot judgements. They must be able to relate the present situation to others previously encountered. ${ }^{10}$ Music teachers may also recognize and relate a student's performance problems to similar problems they have encountered with other students, but in music, it seems more important that the teacher have experience as a performer. While it is useful to know that telling students to play slowly has usually belped them with a particular musical problem, what is more valuable is having worked on the same or similar problems oneself in different performance situations and having found some good ways of solving it. The teacher's own performance experience provides his repertoire of exemplar situations which he then offers to the student. Essential to this approach is the ability to relate a new situation to a familiar one-for the teacher in helping the student, and for the student in learning to think independently. The teacher helps the student build a repertoire of exemplar situations and helps her try out her repertoire with reference to the problem at hand. In this way, she learns to relate the new to the familiar. If a student has learned well, she will not only solve problems in preparation for performance, but will be able to change her interpretation, even in midperformance, to cope with unforeseen situations.

The best person to teach someone to be a reflective practitioner in the field of music would seem then to be a reflective music practitioner, not just a practising musician and not just a reflective teacher. Schon sets out three tasks for the reflective practitioner as teacher: "setting and solving the substantive problems of performance, tailoring demonstration or description to a student's particular needs, and creating a relationship conducive to learning."11

Setting the problem is an important aspect of music teaching. On the most basic level, this task means choosing which element of performance to work on. A particular passage may sound entirely wrong. The causes may be several: the student's finger technique may not be equal to the task, her tone production may lead to forcing high notes so they are sharp and harsh, she may lead into the passage awkwardly, or she may not hear the passage mentally and, thus, not interpret it. Should the teacher concentrate on one or all of these? Will solving one difficulty make the other faults tolerable? Will some problems be solved through other work such as playing scales? The teacher's task is to determine what the problem is, or to redefine the problem so that the student sees the situation differently.

The second task of the reflective practitioner as teacher depends on having some insight into the student's needs; that is, he must be able to guess the 
student's level of understanding, to know whether she responds better to metaphorical descriptions ("Make it dance.") or technical descriptions ("Play the pick-up staccato and accent the downbeat."), and to know when to challenge and when to relax pressure.

The third task is to build a relationship that is conducive to learning. Such a relationship could be of many kinds. Piatagorsky tells of a very talented cellist he taught who became more and more discouraged and played less and less well. Finally, Piatagorsky decided to demonstrate less frequently and to play less well when he did. The student improved remarkably and was heard to comment, "Mr. Piatagorsky is a fine teacher-but what a lousy cellist!" The teacher had achieved his aim. 12 In another anecdote, Piatagorsky describes his own student days living in a boarding house with other students. His teacher, a Mr. Klengel, wanted students to learn from each other. Although he seldom criticized them, he would comment to one student, 'Schneider's vibrato is marvelous!' and everyone would come to 'spy' on Schneider. [But] to Schneider he would say 'Auber's trill is the best.", It worked. 13

Teachers often create an atmosphere of camaraderie among their students, working with them outside the regular lesson time, attending concerts and other social events together, discussing music over dinner. Estelle Liebling, Beverly Sills' teacher from the age of eight, enrolled Sills in a lending library so she would become more cultured and also so she would not spend all her spare time on music; Vengerova, Gary Graffman's teacher from about the same age, sometimes sent an assistant to check on his progress between lessons, in case he had "drifted off course."14 A good teacher-pupil relationship can take many forms, but what makes it good is how well it facilitates the learning of reflective practice. Without a teacher-student relationship that encourages reflection, it is quite possible, even likely, that a student will learn only to imitate the admired teacher. So however much the teacher scolds or shouts, however kind and understanding his manner, however impressive his performance, the student must receive the impression that not only are there alternative ways of playing, but also that other ways are not in themselves final answers either. As Schon puts it, the student must have "the ability to hold ideas loosely."15 He quotes a student in the field of architecture who says of her teacher, "I feel that even if someone is very dominant now, I will always be able to undo it later."16

In summary, a student can learn to think independently within the strictures of the conventional music lesson if she has a teacher who is a reflective music practitioner. Such a teacher "frames" the reality of each musical situation and is, moreover, consciously aware of that framework, recognizing the legitimacy of other ways of looking at the same musical situation. To solve problems in a present situation, he is able to relate this situation to similar situations in his musical experience. Through the teacher's example and coaching, the student builds her own repertoire of exemplar situations and, by experiment, relates them to the problem at hand. In so doing, she may reframe the situation, and so, come to her own autonomously achieved framework of a musical reality.

\section{Creativity}

If it is clear that a music student can learn to make autonomous choices, it may not be so clear that creativity is developed or encouraged in the traditional 
music lesson. There is a concept of creativity which, to over-simplify, sees each child as possessed with ideas unique to her. Direction regarding right and wrong ways of expressing those ideas is seen as stifling. Music, by this definition of creativity, is for the expression of original ideas, and children should be left totally free to let their ideas flow. The traditional music lesson would defeat this purpose. But freedom is actually curtailed by lack of technical direction. Such a deficiency limits possibilities for interpretation at a later stage. Also, among "right" ways of playing, there are many alternatives. In fact, Schon comments, "[Although] music performers work from a score. . .[it] is striking, nevertheless, how many degrees of freedom a musical performer has as she explores and tests alternative ways of designing a performance."17 The freedom of a musical performer is gained through the discipline of acquiring a repertoire of technical solutions to problems of expression. But according to the view described, this is not creativity.

A more realistic view of creativity is that held by Arthur Koestler. "The creative act," he says, "is not an act of creation in the sense of the Old Testament. It does not create something out of nothing; it uncovers, selects, reshuffles, combines, synthesizes already existing facts, ideas, faculties, skills." 18 Koestler views creativity as the ability to perceive a situation in at least two frames of reference, where normally the connection is not apparent. As we have seen, the reflective music practitioner, too, frames reality, relates this framework to another, and in so doing is able to solve unique problems in technique or interpretation. In this sense, she is creative.

We can add to this another notion: the idea that a performer must bring to the music her own personality. James Galway makes this point strongly. He says, "[Music] has to express some emotion [and] you have two responsibilities. One is to play with the sound that reflects your individual qualities. [The other is that] your personal appreciation of the composer's intentions. . .be heard in the way you play."19 The performer, then, is someone who brings to music a personal appreciation of the composer's intentions and unites this knowledge with her knowledge of the characteristics of her own personality. Both spheres admit of several possibilities. Uniting these frames of reference must inevitably make a musical performance creative.

\section{Self-Realization}

Self-realization entails self-knowledge and Galway points out that selfknowledge is necessary in order to be able to reflect one's own personality in one's playing. He breezily recommends yoga, meditation, or "simply. . .contact, abrasive or otherwise, with the rest of the human race 20 as ways to attain self-knowledge. I suggest (and he would probably agree) that his latter suggestion is the most realistic. A music student does not need to search for abrasive contact with the human race. She has a baptism-by-fire that others may lack. To be blunt, it is largely by competing with others that one learns about one's self. Perhaps this is extreme. It is in working with others, by closely interacting-and that includes competition as well as cooperation-that we learn about ourselves. Self-understanding entails knowing one's strengths and weaknesses. Some of these are intellectual, some are physical, and some (perhaps the most important ones) have to do with mental attitudes-willpower, selfdiscipline, ambition, the ability to prioritize, and compromise. We all have 
acquaintances who are certain that they have the talent to write that book or achieve that promotion. Perhaps we share this conviction ourselves. But we may or may not know if we have the necessary mental attitudes to accomplish the task. Such a realization can only come from doing, not from thinking. We test ourselves by experience. The person who claims a potential for success but never quite gets around to it lives under an illusion. Above all other fields, music allows students to test their abilities and preferences and recognize where they excel and where they are limited, which aspects of music they enjoy and which have low priority. They learn about willpower, ambition, jealousy, reaction to stress, and other personal characteristics. The question, of course, is whether they develop destructive attitudes along the way. A highly competitive music student may have little regard for others. But as a realistic assessment of one's self as that self relates to music, there is no doubt that self-knowledge is highly honed in a music education.

When we speak of self-realization, we usually mean the development of all aspects of ourselves. Autonomy, creativity, and self-understanding are three of these; so are our various talents. But a very important part of self-realization is the development of the ability to appreciate, respect, and enjoy ourselves and others as unique human beings, not as "the best," "better than," or "no good" at whatever we do, but as valuable-in-ourselves. It is this final aspect of selfrealization that is likely to be overlooked in a music education. In sports, there is at least a token respect for others in the name of sportsmanship, although it can ring hollow since it is based largely on a tacit respect for effort or prowess. The subject is unlikely to arise at all between music teachers and students. A very sad, but not uncommon phenomenon, is the music student who, having lost a competition, is seen by herself (and, what is worse, her fellow students) as a lesser person. Moreover, jealousy over a contested position can mean the end of civil relations: the musicians fail to see each other as people, only as hated rivals. The self-worth of a musician, and her assessment of others, is often completely tied to her identity as a successful musician. The reflective music teacher must aim not only to develop creative autonomous musicians, but also musicians who take joy in themselves and their fellow humans for what they are as persons, not just as musicians. If Galway is right, such a musician will also bring to the music she plays a richer human understanding and, thus, a more perceptive interpretation.

\section{Notes}

1Joseph Schon, Educating the Reflective Practitioner (San Francisco: Jossey-Bass Publishers, 1987), 176-77.

${ }^{2}$ Schon, Educating the Reflective Practitioner, 178-79.

${ }^{3}$ Schon, Educating the Reflective Practitioner, 182.

${ }^{4}$ Schon, Educating the Reflective Practitioner, 183 ff.

${ }^{5}$ Schon, Educating the Reflective Practitioner, 207-208.

${ }^{6}$ Cited in Schon, Educating the Reflective Practitioner, 177.

${ }^{7}$ Cited in Schon, Educating the Reflective Practitioner, 204.

${ }^{8}$ Joseph Schon, The Reflective Practitioner (New York: Basic Books, 1983), 309-325.

In this discussion, I have used the feminine pronoun to refer to the performer and the masculine pronoun to refer to the teacher. There is a ten- 
dency to assume that music teachers are female and professional musicians are male.

${ }^{10}$ Allen Pearson, The Teacher (New York: Routledge, Chapman and Hall, Inc., 1989), 100.

${ }^{11}$ Schon, Educating the Reflective Practitioner, 182.

${ }^{12}$ Gregor Piatagorsky, Cellist (Garden City, N.Y.: Doubleday \& Co., Ltd., 1965), 116.

${ }^{13}$ Piatagorsky, 64.

${ }^{14}$ Gary Graffman, I Really Should Be Practicing (Garden City, N.Y.: Doubleday \& Co., Ltd., 1981), 46.

${ }^{15}$ Schon, Educating the Reflective Practitioner, 123.

${ }^{16}$ Schon, Educating the Reflective Practitioner, 122.

${ }^{17}$ Schon, Educating the Reflective Practitioner, 209.

${ }^{18}$ Arthur Koestler, The Act of Creation. London: Pan Books Limited, 1966), 119.

${ }^{19} \mathrm{James}$ Galway, Flute (London: Kahn and Avril, 1990), 95.

${ }^{20}$ Galway, 96.

\section{References}

Galway, James. Flute. London: Kahn and Avril, 1990.

Graffman, Gary. I Really Should Be Practicing. Garden City, N.Y.: Doubleday \& Company Limited, 1981.

Kahn, Nathan. "Audition Complaints-Problems and Solutions." In International Musician, 89(1), July 1990.

Koestler, Arthur. The Act of Creation. London: Pan Books Limited, 1966.

Pearson, Allen. The Teacher. New York: Routledge, Chapman and Hall, Incorporated, 1989. 1965.

Piatagorsky, Gregor. Cellist. Garden City, N.Y.: Doubleday \& Co. Ltd.,

Schon, Donald A. Educating the Reflective Practitioner. San Francisco: Jossey-Bass Publishers, 1987.

Schon, Donald A. The Reflective Practitioner. New York: Basic Books, Incorporated, 1983.

Sills, Beverly and Lawrence Linderman. Beverly. Toronto: Bantam Books, 1988. 